\title{
Comparison of Two Different Nutritive Conditions against the Changes in Peripheral Blood Mononuclear Cells of Periparturient Dairy Cows
}

\author{
Hiromichi OHTSUKA ${ }^{1)}$, Chika WATANABE ${ }^{1)}$, Masayuki KOHIRUIMAKI ${ }^{1,2)}$, Takaaki ANDO ${ }^{1)}$, \\ Daisaku WATANABE ${ }^{1)}$, Machiko MASUI ${ }^{2)}$, Tomohito HAYASHI ${ }^{3)}$, Ryo $\mathrm{ABE}^{3)}$, Masateru KOIWA ${ }^{4)}$, \\ Shigeru SATO $^{5)}$ and Seiichi KAWAMURA ${ }^{1)}$
}

${ }^{1)}$ School of Veterinary Medicine and Animal Sciences, Kitasato University, Towada, Aomori 034-8628, ${ }^{2)}$ Kohiruimaki Animal Medical Service, Tohoku, Aomori 039-2683, ${ }^{3)}$ Research Institute for Biological Sciences, Tokyo University of Science, Noda, Chiba 278-0022, ${ }^{4)}$ Department of Large Animal Clinical Sciences, Graduate School of Veterinary Medicine, Rakuno Gakuen University, Ebetsu, Hokkaido 069-8501 and ${ }^{5}$ Department of Miyagi Agricultural Mutual Relief Association, Shiroishi, Miyagi 981-1505, Japan

(Received 6 April 2006/Accepted 6 July 2006)

ABSTRACT. To clarify the relationship between cellular immune status and nutritive condition in periparturient dairy cows, feeding content, blood profiles, and immune condition were observed in cows from two dairy herds with different types of feed content. Immunological analyses such as leukocyte population and peripheral blood mononuclear cell (PBMC) mRNA of IFN- $\gamma$, TNF- $\alpha$, IL-4, and IL-10, quantified by real-time RT-PCR were performed. With regard to feed content during dry periods, there were six cows in the herd with insufficient non-structural carbohydrate (NFC) intake (group I) and six cows in the herd with sufficient NFC intake (group II). Significantly lower levels of blood glucose were observed in group I between weeks -12 and 16 compared with group II. Serum cholesterol level was significantly lower in group I between weeks 2 and 10 than in group II. The numbers of $\mathrm{CD}^{+}$and $\mathrm{CD} 4^{+} \mathrm{T}$ cells in group I were significantly lower than those in group II in weeks 6 and 14. The numbers of CD21 $1^{+} \mathrm{B}$ cells were significantly lower in group I than in group II in weeks $-16,-12,2$, and 10 . On the other hand, the $\mathrm{CD} 4^{+} / \mathrm{CD}^{+}$ratio in group II was significantly higher than group I between weeks 2 and 14. The IFN $\gamma / \mathrm{IL}-4$ mRNA rate in group I was significantly lower than group II in week 6 . We concluded that cellular immune depression occurrs after calving in dairy cows with low nutritional status in the periparturient period.

KEY WORDS: dairy cow, immune function, nutritive conditions, periparturient.

J. Vet. Med. Sci. 68(11): 1161-1166, 2006

Production of high quality milk is one of the goals of dairy farming. Therefore, providing a clean and comfortable environment, usage of proper milking procedures, and maintenance of milking equipment are important for the prevention of mammary gland infections in cows. But, dairy cows characteristically develop new mastitis infections during the first month of lactation $[22,23]$. Immune function suppression in dairy cows appears to occur due to changes in hormones and deficiencies in energy, protein, and several minerals at calving.

It is well known that a suitable nutrition program is necessary to prevent infectious diseases and to produce high quality milk. A previous study $[5,16]$ conducted a thorough general investigation into vitamins and minerals to clarify the relationships between nutrition and immune function in cows. It was recommended that dry and lactating cows fed stored forage receive vitamin E supplemention [16]. In addition, there may be some benefit from adding alphatocopherol to rations or feeding forage with an adequate amount of beta-carotene [5].

We previously reported that the peripheral $\mathrm{CD}^{+}$cell population decreases in months 3 to 5 after calving in cows with a low serum total cholesterol value during the dry period [15]. In mice with mild hypercholesterolemia, fatty degeneration was proportional to IFN $\gamma^{+}$Th1 cells, and mild hypercholesterolemia has been suggested as inducing immune deviation towards a Th1 cell response [12]. On the other hand, in humans, mothers with type 1 diabetes had lower peripheral $\mathrm{CD}^{+}$population levels than healthy controls at delivery [9]. Thus, the nutritive and metabolic conditions in the living body are closely related to the immune function of periparturient dairy cows. Although the relationships between vitamins and minerals and the immune function have previously been studied, little is known about the relationships between the immune function and other nutrients, such as carbohydrates, protein, or fat in dairy cows during the periparturient period. The object of the present study was to clarify the immune conditions in clinically healthy dairy cows with low nutritive conditions as a result of deficient feed content during the periparturient period.

\section{MATERIALS AND METHODS}

Cows: Twelve clinically healthy cows from two herds were used in this study. The feeding contents of the two groups were evaluated according to the Nutrient Requirements of Dairy Cattle (NRC) feeding standards for dairy cows. The required feed nutrient periods were calculated at the peak lactating period to establish production of $40 \mathrm{~kg}$ / day of milk (Table 1). In the close-up period, $5 \mathrm{~kg}$ of marked total mixed ration (TMR), $8 \mathrm{~kg}$ of grass hay, and 2 $\mathrm{kg}$ of grain feeding were given to the cows in group I, and 5 $\mathrm{kg}$ of TMR (same type with group I), $8 \mathrm{~kg}$ of grass hay, and $4 \mathrm{~kg}$ of grain feeding were given to the cows in group II. The feed during the dry and close-up periods given to group 
Table 1. Feeding sufficiency and contents for two groups

\begin{tabular}{ccrr}
\hline Milking Stage & & Group I & Group II \\
\hline Dry & CP (\%) & 90.6 & 94.6 \\
(day-60 to -31) & DIP (\%) & 108.8 & 108.8 \\
& SIP (\%) & 104.7 & 100.0 \\
& TDN (\%) & 113.1 & 112.6 \\
\cline { 2 - 4 } & NDF (\%) & 63.8 & 51.4 \\
& ADF (\%) & 37.5 & 27.7 \\
& NFC (\%) & 13.6 & 27.3 \\
\hline Close-up & CP(\%) & 100.6 & 107.5 \\
(day -30 to calving day) & DIP(\%) & 118.6 & 112.2 \\
& DIP (\%) & 106.5 & 98.0 \\
& TDN (\%) & 108.3 & 113.4 \\
\cline { 2 - 4 } & NDF (\%) & 54.7 & 44.6 \\
& ADF (\%) & 31.8 & 24.2 \\
& NFC (\%) & 21.3 & 32.3 \\
\hline Peak & CP (\%) & 97.3 & 90.2 \\
(day 61 to 120) & DIP (\%) & 107.6 & 96.2 \\
& SIP (\%) & 89.0 & 86.5 \\
& TDN (\%) & 100.2 & 100.3 \\
\cline { 2 - 3 } & NDF (\%) & 36.0 & 37.5 \\
& ADF (\%) & 19.2 & 20.8 \\
& NFC (\%) & 35.3 & 36.5
\end{tabular}

Data are mean percentages according with NRC standards. The rate of feeding sufficiency was set as a body weight (BW) of 650 $\mathrm{kg}$ in all cows. In all cows, the target milk yield was $40 \mathrm{~kg}$ per day at the peak period.

I $(\mathrm{N}=6)$ was part of an experimental program which given feeds with low amounts of non-structural carbohydrate (NFC) and high amounts of neutral detergent fiber (NDF) compared with the ranges recommended by the NRC. The feed content of these ingredients were within the recommended ranges in herd of group II $(\mathrm{N}=6)$.

Blood analysis: Blood samples were collected in tubes containing anticoagulant heparin, sodium fluoride, or dipotassium-EDTA, or no anticoagulant, between 1 and 3 p.m. Serum samples were used to measure the serum total cholesterol (enzyme assay), non-esterified fatty acid (NEFA; enzyme assay) and blood urea nitrogen (urease indophenol method), and the plasma samples with sodium fluoride were used to measure blood glucose (enzyme assay). Total white blood cell (WBC) counts were determined with a blood cell counter. The schedule for blood collections from cows was according to the expected calving dates and included collection of 8 blood samples, on weeks -16, -12, -7, -3 (before calving), and $1,5,10$, and 14 after calving.

Flow cytometry: WBC samples were suspended in cold PBS, and $1 \times 10^{6}$ cells were incubated with various primary monoclonal antibodies for one hour. The lineage-specific monoclonal antibodies (VMRD, Pullman, WA, U.S.A.) used were MMIA (pan T lymphocyte, CD3 antigen), CACT183A (T-helper lymphocyte, CD4 antigen), BAT82A (T-cytotoxic/suppressing lymphocyte, CD8 antigen), BAQ15A (B lymphocyte, CD21 antigen), GC6A (non-activated leukocyte, CD45R antigen), CAT82A (monocyte/B lymphocyte, MHC class II antigen), and MY-4 (monocyte,
CD14 antigen; Coulter Immunology, Hialeah, Florida, U.S.A.). Two-color flow cytometric analysis was performed. To measure the PBMC population, cells were stained with fluorescein isothiocyanate (FITC) or phycoerythrin (PE)-labeled secondary antibody (Cappel, Durham, NC, U.S.A.). Samples were analyzed by FACScan (BD Biosciences Immunocytometry Systems, San Jose, Cal.) using Lysis II software. The data from $1 \times 10^{4}$ cells was analyzed for each sample.

Real-time PCR: First, $2 \times 10^{6} \mathrm{PBMC}$ in a total volume of $1 \mathrm{~m} l$ of $10 \%$ FCS-RPMI were placed in a 24-well plate and stimulated with phytohemagglutinin (PHA) (Sigma-Aldrich CO, St.Louis, U.S.A.) $(5 \mu \mathrm{g} / \mathrm{m} l)$ for $12 \mathrm{hr}$ at $37^{\circ} \mathrm{C}$. After incubation, PBMC pellets were collected at the indicated times. Subsequently, the supernatants were removed, and the cells were resuspended using TRIzol reagent (Invitrogen, Carlsbad, CA, U.S.A.).

Two micrograms of total RNA from each sample were used for synthesis of first-strand cDNA with oligo-dT primers (Invitrogen, Carlsbad, CA, U.S.A.) and Superscript II Reverse Transcripts (Invitrogen, Carlsbad, CA, U.S.A.) according to the manufacturer's protocols. Real-time PCR was performed with SYBR Green Master Mix on an ABI prism 7700 Sequence Detector (Applied Biosystems, Foster City, CA, U.S.A.). The target DNA sequence was specifically amplified with the primers as previously designed (IL4, IL-10, IFN- $\gamma$, TNF- $\alpha$ ) [17]. The melting curve was determined for each PCR product. The comparative threshold cycle number $\left(2^{\Delta \Delta C t}\right)$ method was used after a validation experiment demonstrated that the efficiencies of the target and reference ( $\beta$-actin) were approximately equal. Ct values define the threshold cycle of PCR, at which amplified products were detected. The results are presented as $\Delta \mathrm{Ct}$ values, where $\Delta \mathrm{Ct}$ is the difference in threshold cycles for the target and $\beta$-actin as an internal control. Fold changes in expression for the two groups $(\Delta \mathrm{Ct})$ were calculated using the formula $2-{ }^{\Delta \Delta \mathrm{Ct}}$ as previously described [10].

Statistical Analysis: Statistical analysis was performed using repeated measures two-way ANOVAs for each milking stage in the two groups, and values of $P<0.05$ were regarded as significant using the Student's test. Mean values and standard errors were calculated for the clinical and laboratory data.

\section{RESULTS}

No clinical signs that indicated a disease were observed in all cows during the experimental periods. The level of blood glucose in group I was significantly lower than in group II between weeks -12 and 6 . The serum total cholesterol level in both groups decreased gradually before calving, and these levels increased after calving. The serum total cholesterol level in group I was significantly lower than in group II between weeks 2 and 10. The blood glucose and serum total cholesterol levels in group I were lowest in week 2 (Fig. 1). The levels of blood urea nitrogen and serum NEFA in the two groups were stable, and no signifi- 
(1)

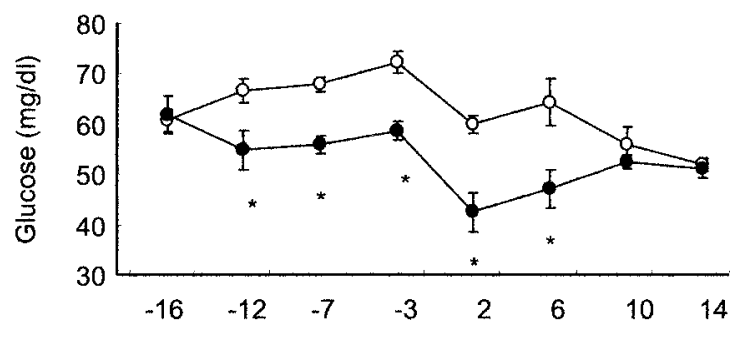

(2)

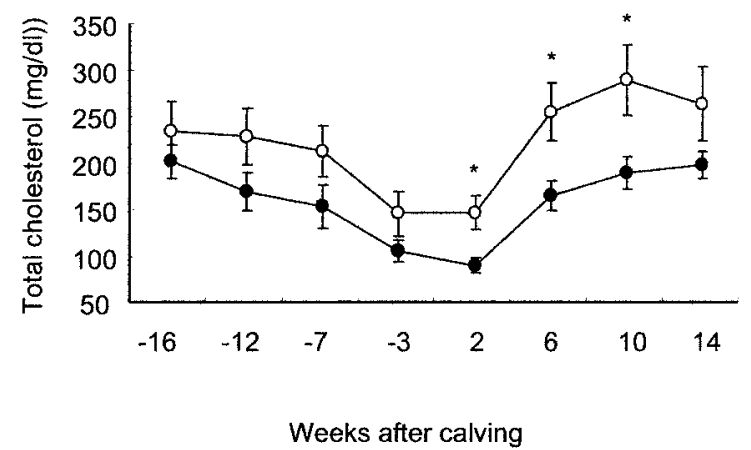

Fig. 1. Changes in the blood glucose (1) and total cholesterol (2) levels in group I $(\mathbf{O})$, and group II $(\bigcirc)$. Values are expressed as the mean \pm S.E. Asterisks indicate indicate significant differences between the two groups $(P<0.05)$.

cant differences were detected (data not shown).

The numbers of $\mathrm{CD}^{+}$and $\mathrm{CD}^{+} \mathrm{CD}^{+} 5 \mathrm{R}^{-} \mathrm{T}$ cells in both groups decreased gradually after calving, and the number of these cells was significant lower in group I than in group II in weeks 6 and 14. The number of $\mathrm{CD}^{+} \mathrm{CD}^{4} 5 \mathrm{R}^{+} \mathrm{T}$ cells in group I was lower than in group II during the experimental periods. There were significantly lower numbers of these $\mathrm{T}$ cells in group I in weeks 6 and 14 after calving (Fig. 2). The number of $\mathrm{CD}^{+} \mathrm{T}$ cells in group I was lower after calving compared with group II, and significantly low numbers were observed in weeks 2,6 , and 14 . No significant differences in the numbers of $\mathrm{CD}^{+}$cells were detected between 2 groups. The numbers of MHC class- $\mathrm{II}^{+}$cells and $\mathrm{CD} 21^{+}$ cells in group I were lower than in group II during the experimental periods. There were significantly low numbers of MHC class- $\mathrm{II}^{+}$cells in group I in weeks $-16,-12,2$, and 10 , and significantly low numbers of $\mathrm{CD} 21^{+}$cells in week 2 compared with group II (Fig. 3).

There was no evidence of changes in the levels of IFN- $\gamma$, TNF- $\alpha$, and IL-4 mRNA in both groups during the experimental period. The level of IL-10 mRNA increased after week -12 , peaked in week -3 , and then decreased sharply after calving, and there was a significant difference at week -3 between the 2 groups (Fig. 4).

The $\mathrm{CD}^{+} / \mathrm{CD}^{+}$ratio in group II increased gradually after week -12 and peaked in week 14 after calving. There
(1)

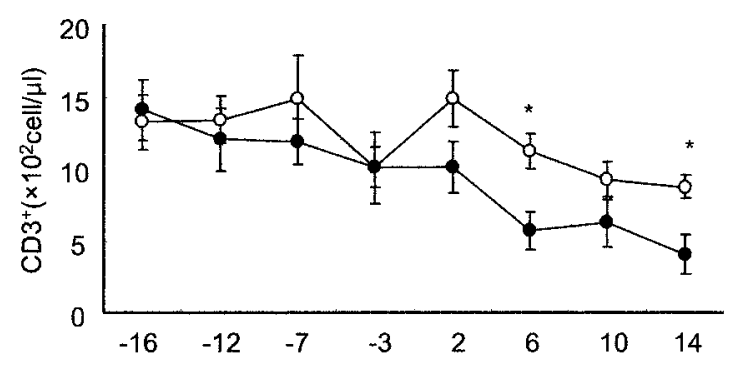

(2)

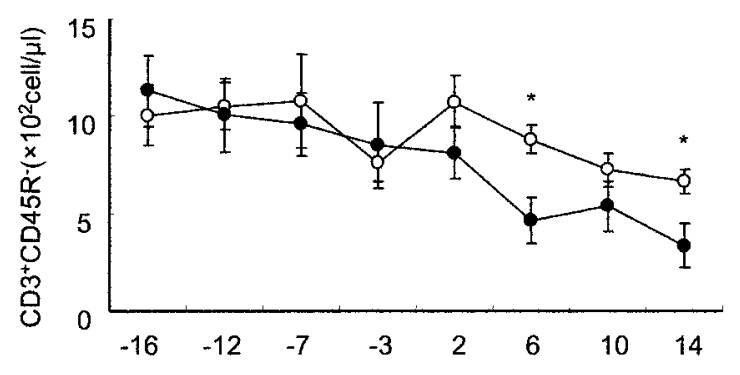

(3)

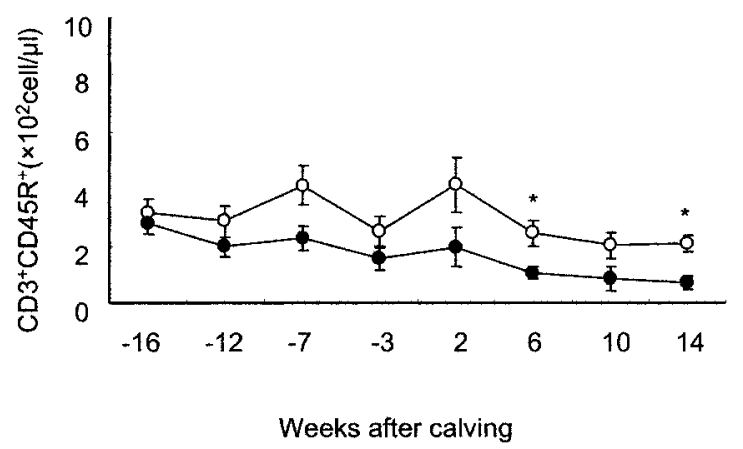

Fig. 2. Changes in the numbers of $\mathrm{CD}^{+}(1), \mathrm{CD}^{+} \mathrm{CD}^{+} 5 \mathrm{R}^{-}(2)$, and $\mathrm{CD}^{+} \mathrm{CD} 45 \mathrm{R}^{+}(3)$, T cells in group I $(\mathbf{O})$, and group II (O). Values and symbols as per Fig. 1.

was a significantly low $\mathrm{CD} 4^{+} / \mathrm{CD}^{+}$ratio in group I compared with group II after calving. The IFN- $\gamma / \mathrm{IL}-4$ mRNA ratio in group I increased after week 2 , and a significantly high ratio was detected in week 6 compared with group II (Fig. 5).

\section{DISCUSSION}

During early postpartum, increases in plasma cholesterol concentrations coincide with increases in DMI [3]. The serum cholesterol response is suggested to be dependent on the level of DMI, and dairy cows require moderate NFC in feed content to acquire sufficient DMI. We suggest that providing a sufficient amount of NFC is very important for rumen fermentation. The important causes of the long last- 
(1)

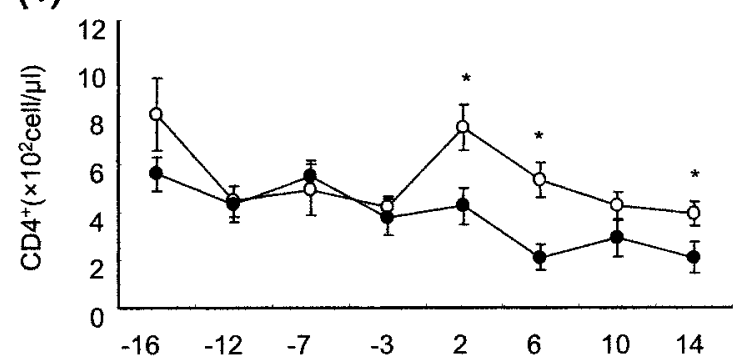

(2)

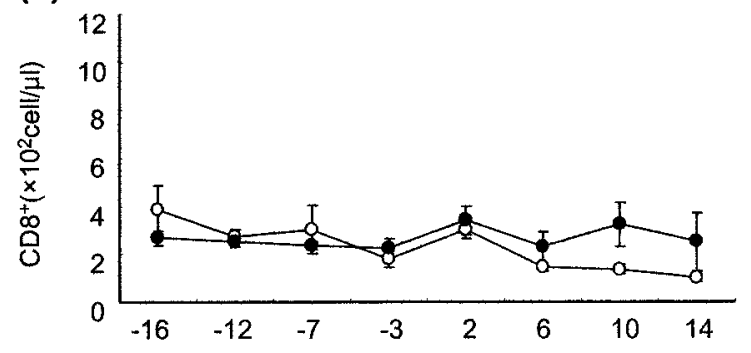

(3)

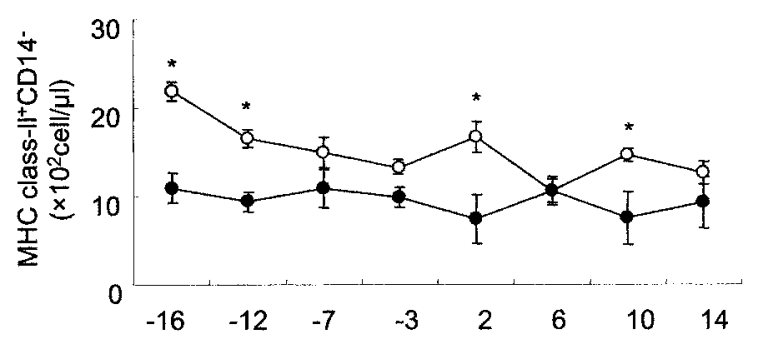

(4)

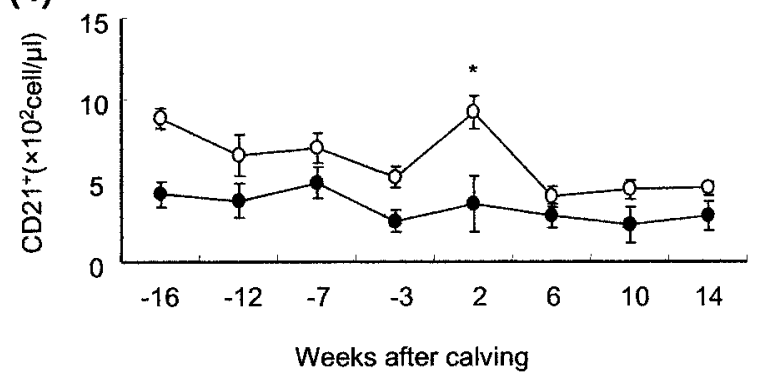

Fig. 3. Changes in the numbers of $\mathrm{CD}^{+}(1)$ and $\mathrm{CD}^{+}(2) \mathrm{MHC}$ class $\mathrm{II}^{+} \mathrm{CD} 14^{-}(3)$, and $\mathrm{CD} 21^{+}(4)$ cells in group I (O) and group II (O). For further comments, see the legend to Fig. 1.

ing low blood glucose and total cholesterol levels in group I seem to be partly due to a low level of NFC in the feeding plan in the dry period.

In this study, the cows in group I were identified as undernourished because of low blood glucose and total cholesterol levels during the periparturient period. It is well known that the percentages of peripheral $\mathrm{CD}^{+}$and $\mathrm{CD}^{+} \mathrm{T}$ cells decrease and then return to normal levels in healthy
(1)

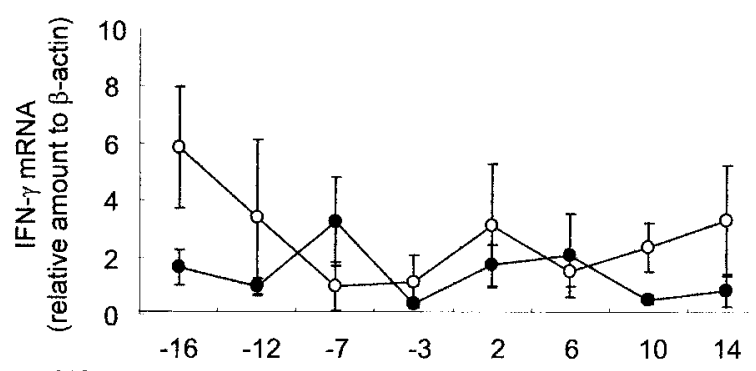

(2)

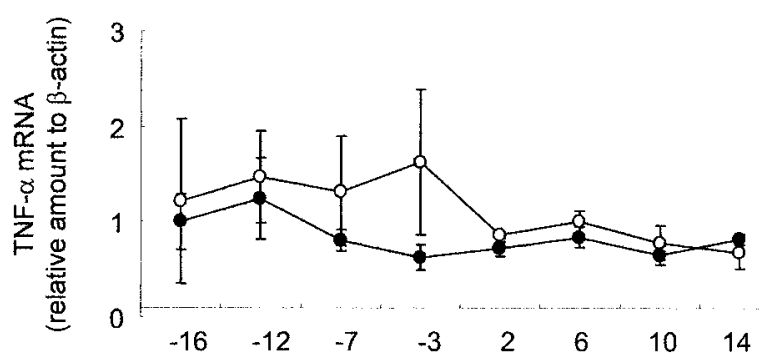

(3)

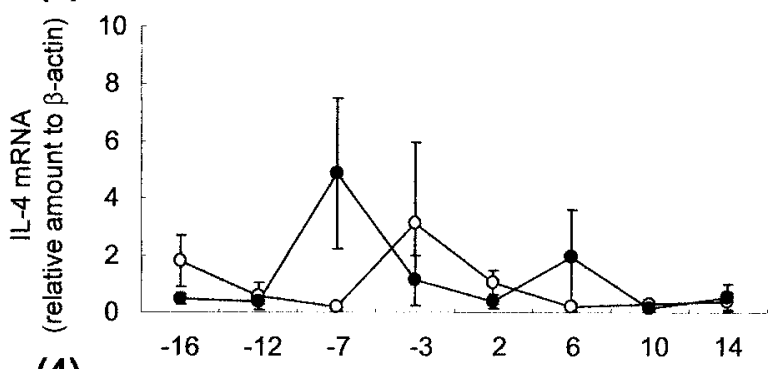

(4)

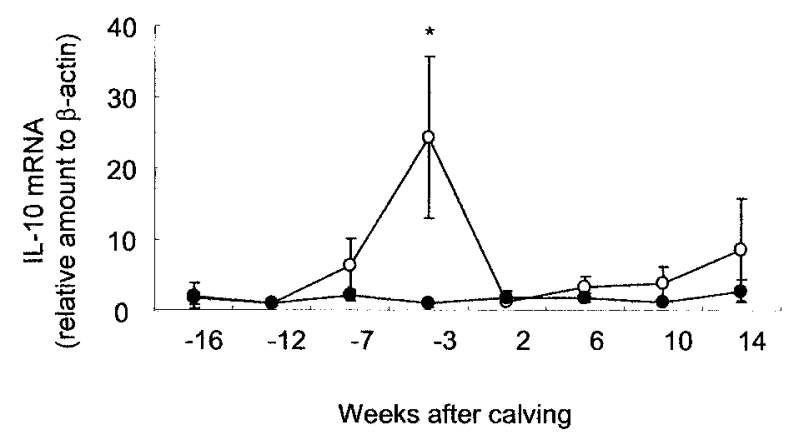

Fig. 4. Changes in the levels of IFN- $\gamma$ (1) and TNF- $\alpha$ (2), IL-4 (3), and IL-10 (4) mRNA in group I (O) and group II (O). For further comments, see the legend to Fig. 1.

cows around calving [8]. In cows with a low serum total cholesterol level during the periparturient period, the peripheral $\mathrm{CD}^{+} \mathrm{T}$ cell population remained low until several months postpartum compared with cows with normal serum total cholesterol levels [14]. These results resemble the changes in the $\mathrm{CD}^{+} \mathrm{T}$ cells in group II. Moreover, whereas the percentages of $\mathrm{CD}^{+}$and $\mathrm{CD}^{+} \mathrm{T}$ cells in the 
(1)

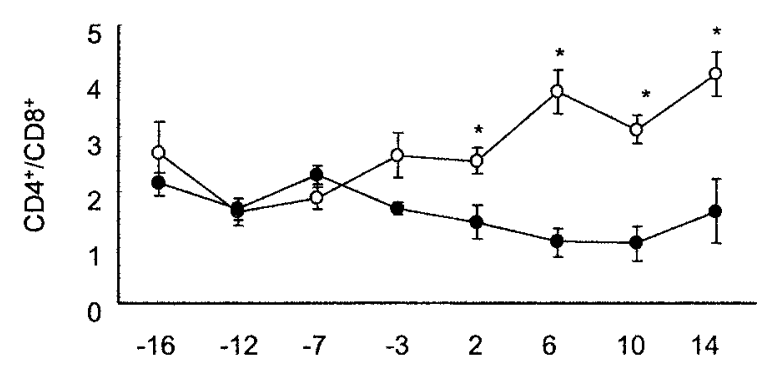

(2)

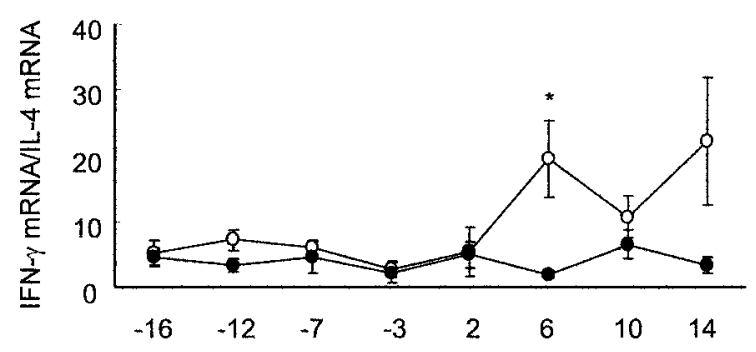

Weeks after calving

Fig. 5. Changes in the ratios of $\mathrm{CD}^{+} / \mathrm{CD} 8^{+}(1)$ and IFN- $\gamma / \mathrm{IL}-4$ (2) in group I $(\bigcirc)$ and group II $(\bigcirc)$. For further comments, see the legend to Fig. 1.

two groups were stable before calving, we found the number of $\mathrm{CD}^{+} \mathrm{T}$ cells were significantly lower in group I than group II after calving. Lower $\mathrm{CD}^{+} \mathrm{T}$ cell have been observed in calves with hypocholesteremia and hypoglycemia [15]. Malnutrition causes severe immunodeficiency with depletion of $\mathrm{CD}^{+} \mathrm{T}$ cells and reduction of cell mediated immunity. Trends of fewer $\mathrm{CD}^{+} \mathrm{T}$ cells and less IL-2 production in response to mitogen have been observed in men with low cholesterol, compared with men with high cholesterol levels [12]. Lymphocytes consume blood glucose, and the energy-demanding processes of cell growth and proliferation are accompanied by an increase in blood glucose utilization [6]. Recently, cholesterol has become acknowledged as an important component in maintaining proximal signaling of the membrane microdomains in lymphocytes [7]. Thus, the loss of cholesterol or blood glucose might reduce immune function, production of cytokines, or differentiation of lymphocytes in lactating cows.

During the prepartum period, a marked difference in the number of $\mathrm{T}$ cells was not detected, but compared with group II significantly lower numbers of B cells in group I were observed. We found lower cholesterol levels and small B cell numbers during the middle and latter lactating to dry periods in undernourished herds [13]. A low percentage of peripheral B cells was found during the dry period in peripartum cows with low serum cholesterol [15]. These investigations are resemble to this result, and it is possible that a small number of $\mathrm{B}$ cells is a characteristic change in undernourished periparturient cows. The percentages of $\mathrm{CD} 19^{+} \mathrm{B}$ lymphocytes were reported to be lower in women with pregnancy failures than healthy humans [4]. Because a small number of peripheral B cells seems to be an abnormal immune condition in periparturient cows, it is unclear whether this small number synergistically affect the immune function in cows with low nutritional status.

It is recognized that TNF- $\alpha$ contributes to physiological insulin resistance during the course of normal pregnancy and is involved in fetal growth impairment during development through the suppression of transplacental passage of amino acids and blood glucose $[2,11]$. On the other hand, IL-10 is increased in pregnant woman compared with nonpregnant woman [1]. As suggested by our cytokine results for group II during the dry period, elevated TNF- $\alpha$ and IL10 may be the physiological consequences of a normal pregnancy. A previous study showed decreased IL-2 and IFN- $\gamma$ production from PBMCs in humans with malnutrition [18, 20]. Therefore, the reduction in cytokine production in group I may be due to a reduced capacity of immune cells to produce cytokines.

It has been reported that there are high IL-4 and low IFN$\gamma$ levels in $\mathrm{CD}^{+} \mathrm{T}$ cells isolated postpartum compared with the middle- and late lactation periods in dairy cows [21]. In this study, a significantly lower $\mathrm{CD}^{+} / \mathrm{CD}^{+}$ratio and IFN$\gamma / \mathrm{IL}-4$ mRNA balance in PBMCs existed between group I and group II after calving. These marked T-cell immunoregulatory abnormalities in group I were found after calving. IFN- $\gamma$ is a key cytokine in the development of cellular immune responses that is required for the elimination of pathogens, inducement of differentiation, activation of monocytes/macrophages and enhancement of their microbicidal effector functions [24]. A negative energy balance induces a decrease in blood glucose and cholesterol and is related to metabolic diseases such as ketosis, milk fever, and displaced abomasum at calving [19]. Cows with nutritional management disorders in the transition period have an increased incidence of metabolic diseases as a result of low DMI and an increased incidence of undernourishment after calving. In a previous study, it was found that the activation capability of $\mathrm{CD}^{+} \mathrm{T}$ cells and IL- 2 and IFN- $\gamma$ production were considerably decreased in malnourished humans $[18$, 20]. These findings as described above suggest that the low ratios of $\mathrm{CD}^{+} / \mathrm{CD}^{+}$and IFN- $\gamma / \mathrm{IL}-4$ mRNA in group I are related closely to hypocholesteremia and hypoglycemia as a result of low DMI.

It is known that dairy cows experience a rapid increase in milk yield and slow rise in DMI, and that undernourishment will be compensated for by adipose tissue mobilization in the early lactation period. Moreover, cows with metabolic diseases have a seriously depressed appetite and develop a more undernourished condition. The effects of undernourishment appear to be the loss of immune cell functions, and an increase in host susceptibility to infectious diseases. We suggest that maintaining effective DMI is important for ani- 
mals, particularly high yielding dairy cows, in early lactation in order to maintain improved resistance against infection.

\section{REFERENCES}

1. Bates, M.D., Quenby, S., Takakuwa, K., Johnson, P.M. and Vince, G.S. 2002. Aberrant cytokine production by peripheral blood mononuclear cells in recurrent pregnancy loss? Human Repro. 17: 2439-2444.

2. Carbo, N., Lopez-Soriano, F.J. and Argiles, J.M. 1995. Administration of tumor necrosis factor-alpha results in a decreased placental transfer of amino acids in the rat. Endocrinology 136: 3579-3584.

3. Carroll, D. J., Jerred, M. J., Grummer, R. R., Combs, D. K., Pierson, R. A. and Hauser, E. R. 1990. Effect of fat supplementation and immature alfalfa to concentrate ratio on plasma progesterone, energy balance, and reproductive traits of cattle. J. Dairy Sci. 73: 2855-2863.

4. Darmochwal-Kolarz, D., Leszczynska-Gorzelak, B., Rolinski, J. and Oleszczuk, J. 2002. The immunophenotype of patients with recurrent pregnancy loss. Eur. J. Obstet. Gynecol. Reprod. Biol. 103: 53-57.

5. Fountain, M.W., Dees, C., Weete, J.D. and Schultz, R.D. 1982. Interactions of multilamellar phospholipid vesicles with bovine lymphocytes: effects of alpha-tocopherol on lymphocyte blastogenesis. Mol. Immunol. 19: 1491-1498.

6. Frauwirth, K.A. and Thompson, C.B. 2004. Regulation of T lymphocyte metabolism. J. Immunol. 172: 4661-4665.

7. Gimpl, G., Burger, K. and Fahrenholz, F. 1977. Cholesterol as modulator of receptor function. Biochemistry 36: 1095910974.

8. Kimura, K., Goff, J.P., Kehrli, M.E. and Jr, Harp, J.A. 1999. Phenotype analysis of peripheral blood mononuclear cells in periparturient dairy cows. J. Dairy Sci. 82: 315-319.

9. Lapolla, A., Dalfra, M.G., Sanzari, M., Fedele, D., Betterle, C., Masin, M., Zanchetta, R., Faggian, D., Masotti, M., Nucera, V. and Plebani, M. 2005. Lymphocyte subsets and cytokines in women with gestational diabetes mellitus and their newborn. Cytokine 21: 280-287.

10. Livak and Schmittgen. 2001. Analysis of relative gene expression data using real-time quantitative PCR and the 2(-Delta Delta C(T)) Method. Methods 25: 402-408.

11. Melczer, Z., Banhidy, F., Csomor, S., Kovacs, M., Siklos, P., Winkler, G. and Cseh, K. 2002. Role of tumour necrosis factoralpha in insulin resistance during normal pregnancy. Eur. J. Obstet. Gynecol. Reprod. Biol. 105: 7-10.

12. Muldoon, M.F., Marsland, A., Flory, J.D., Rabin, B.S., Whiteside, T.L. and Manuck, S.B. 1997. Immune system differences in men with hypo- or hypercholesterolemia. Clin. Immunol.
Immunopathol. 84: 145-149.

13. Ohtsuka, H., Kohiruimaki, M., Hayashi, T., Katsuta, K., Matsuda, K., Masui, M., Abe, R. and Kawamura, S. 2006. Relationship between Leukocyte Population and Nutritive Conditions in Dairy Herds with Frequently Appearing Mastitis. J. Vet. Med. Sci. 68, (in press).

14. Ohtsuka, H., Fukunaga, N., Fukuda, S., Hatsugaya, A., Hayashi, T., Hara, H., Koiwa, M., Abe, R. and Kawamura, S. 2005. Effect of nutritional conditions on changes in leukocyte populations in Japanese black calves. J. Vet. Med. Sci. 67: 183185.

15. Ohtsuka, H., Koiwa M., Sato, Y., Yamashita, M., Takada, T., Itoh, N., Hoshi, F., Yoshino, T. and Kawamura, S. 2001. Relationship between serum total cholesterol during dry period and peripheral leukocyte after calving in healthy dairy cows. J. Jpn. Vet. Med. Assoc. 54: 101-105.

16. Politis, I., Hidiroglou, N., White, J.H., Gilmore, J.A., Williams, S.N., Scherf, H. and Frigg, M. 1996. Effects of vitamin E on mammary and blood leukocyte function, with emphasis on chemotaxis, in periparturient dairy cows. Am. J. Vet. Res. 57: 468-471.

17. Riollet, C., Rainard, P. and Poutrel, B. 2001. Cell subpopulations and cytokine expression in cow milk in response to chronic Staphylococcus aureus infection. J. Dairy Sci. 84: 1077-1084.

18. Rodriguez, L., Gonzalez, C., Flores, L., Jimenez-Zamudio, L., Graniel, J. and Ortiz, R. 2005. Assessment by flow cytometry of cytokine production in malnourished children. Clin. Diagn. Lab. Immunol. 12: 502-507.

19. Rukkwamsuk, T., Kruip, T.A. and Wensing, T. 1997. Relationship between overfeeding and overconditioning in the dry period and the problems of high producing dairy cows during the postparturient period. Vet. Q. 21: 71-77.

20. Savendahl, L. and Underwood, L.E. 1997. Decreased interleukin-2 production from cultured peripheral blood mononuclear cells in human acute starvation. J. Clin. Endocrinol. Metab. 82: $1177-1780$.

21. Shafer-Weaver, K.A., Corl, C.M. and Sordillo, L.M. 1999. Shifts in bovine $\mathrm{CD} 4^{+}$subpopulations increase T-helper-2 compared with T-helper-1 effector cells during the postpartum period. J. Dairy Sci. 82: 1696-1706.

22. Smith, K., Todhunter, D. A. and Schoenberger. P. S. 1985. Environmental mastitis: cause, prevalence, prevention. $J$. Dairy Sci. 73: 1531-1553.

23. Smith, K. L., D. A. Todhunter, and Schoenberger, P. S. 1985. Environmental pathogens and intra-mammary infection during the dry period. J. Dairy Sci. 68: 402-417.

24. Young, H. A. and Hardy, K. J. 1995. Role of interferon- $\gamma$ in immune cell regulation. J. Leukoc. Biol. 58: 373-381. 